\title{
Evaluation of five screening tests licensed in Argentina for detection of hepatitis $\mathrm{C}$ virus antibodies
}

\section{Viviana Ré/ ${ }^{+}$, Sandra Gallego, Elena Treviño*, Gabriela Barbás, Claudia Domínguez*, O svaldo Elbarcha**, Héctor Bepre*, Marta Contigiani}

\author{
Instituto de Virología “Dr. J. M. Vanella”, Facultad de Ciencias Medicas *Instituto de Hemoterapia y Hematología, Universidad \\ Nacional de Córdoba, Enfermera Gordillo Gómez s/n, Ciudad Universitaria (5016) Córdoba, Argentina **Cátedra de Virología, \\ Facultad de Ciencias Químicas, Universidad Católica de Córdoba, Argentina
}

This study was conducted to compare among the most recent generation of five screening tests licensed in Argentina, in order to evaluate which of the tests has the best sensitivity for detection of antibodies against hepatitis $C$ virus $(\mathrm{HCV})$.

The tests analyzed were: Detect-HCV ${ }^{T M}$ (3.0) Biochem ImmunoSystems, Canada; Hepatitis C EIA Wiener Lab., Argentina; Equipar HCV Ab, Italy; Murex HCV 4.0, UK and Serodia-HCV particles agglutination test, Japan.

The results obtained showed high discrepancy between the different kits used and show that some of the tests assessed have a low sensitivity for anti-HCV detection in both chronic infections and early seroconversion, and indicate that among the commercially available kits in Argentina, Murex HCV 4.O (UK) and Serodia-HCV particles agglutination test (Japan) have the best sensitivity for HCV screening.

Although the sensitivity of the assays is the first parameter to be considered for blood screening, more studies should be carried out to assess the specificity of such assays.

Key words: hepatitis C virus (HCV) - HCV screening test - sensitivity

Hepatitis $\mathrm{C}$ virus (HCV) produces a persistent infection in humans and a high proportion of infected subjects develop a chronic liver disease. This virus is strongly associated with progressive liver pathology, including cirrhosis, hepatic failure, and hepatocellular carcinoma. The main route of transmission is parenteral and most of the individuals infected with HCV are either intravenous drug users or recipients of blood products (Van der Poel et al. 1991, Weber et al. 1995).

The laboratory diagnosis of HCV infection depends primarily on detecting $\mathrm{HCV}$ antibodies (anti-HCV) by enzyme immunoassays (EIAs) or particle agglutination assay (PA). The sensitivity of a diagnostic test is defined as its ability to detect the infection in subjects who actually have the infection. Subjects with or without infection must be defined using most sensitive and specific assays previously validated as gold standard. Although there is no consensus about a reference assay for diagnosis of $\mathrm{HCV}$ infection, detection of HCV RNA is recommended (Lunel et al.1996, Colin et al. 2001).

Similar to other viral infections, the window period in $\mathrm{HCV}$ infection is still a major problem for blood safety. During the window period, specific antibodies are not detectable but the virus is present in blood. For this reason, antibodies tests are unable to identify the subjects in this early stage of infection. The stage prior to seroconversion may last up to 2 months in immunocompetent subjects and as long as 6 to 12 months in immunodeficient patients (Van der Poel et al. 1994, Schreiber et al.

${ }^{+}$Corresponding author. E-mail:contigia@ $@$ cmefcm.uncor.edu Received 9 September 2004

Accepted 28 March 2005
1996, Stramer et al. 1998, Muerhoff et al. 2002).

Since the risk of virus transmission by blood during the "window period" is high, the most sensitive assay must be used for screening of HCV among blood donors to reduce false negative results.

The first serological assay for HCV detection was marketed in 1989 and consisted on an indirect EIA procedure using recombinant $\mathrm{C} 100-3$ protein originated from a non-structural 4 (NS4) genomic region. This first generation test was extremely useful in reducing the risk of posttransfusion HCV infection. However, the length of the seronegative window period in some donors resulted in $\mathrm{HCV}$ transmission in antibody-screened blood (Aach et al. 1991).

The second-generation assay marketed in 1991 included capsid antigens and non-structural region antigens (NS3 and NS4) and had increased sensitivity and specificity (Janot et al. 1992, Kleinman et al. 1992). The long negative antibody period associated with the first generation test was reduced by an average of five weeks (Majid \& Gretch 2002).

In 1993, third-generation assays became available. Most of them use recombinant proteins or synthetic peptides allowing the detection of antibodies against the core, NS3, NS4, and NS5 viral proteins. In the third-generation assays, reconfigured core antigen has lead to a very modest increase in sensitivity, although in the majority of cases, no differences in the time to seroconversion were found using third-generation compared to second-generation assays (Morishima 1999).

The aim of the present study was to compare among the most recent generation of five screening tests licensed in Argentina, in order to evaluate which of the tests has the best sensitivity for detection of antibodies against HCV. 


\section{MATERIALS AND METHODS}

Serum samples - Twenty two serum samples from patients infected with $\mathrm{HCV}$ were analyzed for the presence of anti-HCV antibodies. All samples were obtained from patients with confirmed HCV infection and studied by qualitative RT-Nested PCR (Mendes de Oliveira et al. 2001). The levels of HCV-RNA were quantitatively determined with Amplicor HCV 2.0 test (Roche Diagnostics, Branchburg, NJ, US).

Serological tests - The presence of anti-HCV antibodies was investigated by using the most recent generation of different $\mathrm{HCV}$ antibody screening tests licensed in Argentina: 1) Detect-HCV ${ }^{\mathrm{TM}}$ (3.0) Biochem ImmunoSystems Inc., Montreal, Quebec, Canada; 2) Hepatitis C (anti-HCV) EIA Wiener Lab., 2000 Rosario, Argentina; 3) Equipar HCV Ab, Saronno (Va), Italy; 4) Murex HCV 4.0, Dartford, UK, and 5) Serodia-HCV particles agglutination test, Fujirebio Inc., Tokio, Japan.

All the antibodies assays were carried out and interpreted according to manufacturers' instructions. The samples were tested in triplicate using each assay.

The results of EIA tests were expressed as the ratio between the mean of the optical densities (OD) of each serum sample and the cut-off value (CO). Sera with ratios $>1.1$ were considered positive.

\section{RESULTS}

The results of the HCV antibodies detection by the different screening tests are shown in Table I.
All the positive serum samples tested $(n=22)$ were positive by EIA Wiener (anti-HCV), Murex HCV and Serodia-HCV PA assays. Twenty out of the 22 positive samples were positive by Detect-HCV ${ }^{\mathrm{TM}}$ and 21 resulted reactive by Equipar $\mathrm{HCV} \mathrm{Ab}$. Although, the two samples not detected by Detect-HCV ${ }^{\mathrm{TM}}$ kit resulted positive by EIA Wiener (anti-HCV) kit; the OD/CO values were low using this last assay (Table I). The sensitivity was: $100 \%$ for EIA Wiener (anti-HCV), Murex HCV (v 4.0) and SerodiaHCV PA, 90.9\% for Detect-HCV ${ }^{\mathrm{TM}}$ and $95.4 \%$ for Equipar $\mathrm{HCVAb}$.

The comparison between the OD/CO values of each sample with the corresponding viral load in plasma showed that there was not a direct relationship between these parameters. This is supported by the fact that the OD/CO values of the samples with higher viral load were similar or lower than the OD/CO values of some samples with lower viral load (Table I). Furthermore, one of the samples with $\mathrm{HCV}$ viral load of 13,700 IU/ml resulted negative for anti-HCV antibodies using some of the serological kits (Table I).

Due to the false negative results found in two of the positive samples, we evaluated the sensitivity of the same serological kits for detection of anti-HCV in five retrospective and prospective serum samples from a subject infected with HCV through a blood transfusion. These results are shown in Table II.

Our results showed a high discrepancy between the serological kits evaluated for the early detection of antibodies against HCV. Murex HCV and Serodia-HCV PA

TABLE I

Detection of antibodies against hepatitis $\mathrm{C}$ virus (HCV) using five different screening tests

\begin{tabular}{|c|c|c|c|c|c|c|}
\hline \multirow[b]{2}{*}{ Sample } & \multicolumn{5}{|c|}{ Antibodies against $\mathrm{HCV}$} & \multirow{2}{*}{$\begin{array}{c}\text { Viral load (IU/ml) } \\
\text { Amplicor HCV } 2.0 \\
\text { (Roche) }\end{array}$} \\
\hline & $\begin{array}{c}\text { Detect } \\
\text { HCV }^{\mathrm{TM}}\end{array}$ & $\begin{array}{l}\text { EIA Wiener } \\
\text { (anti-HCV) }\end{array}$ & $\begin{array}{l}\text { Equipar } \\
\mathrm{HCV} \mathrm{Ab}\end{array}$ & Murex HCV & $\begin{array}{c}\text { Serodia } \\
\text { HCV PA }\end{array}$ & \\
\hline $01 \mathrm{R}$ & 6.8 & 13.05 & $>8.13$ & 5.30 & Reactive & 2,100 \\
\hline 02B & 5.8 & 12.75 & $>8.13$ & 5.37 & Reactive & 3,900 \\
\hline $03 \mathrm{~F}$ & 6.7 & 12.87 & 7.06 & 5.38 & Reactive & 13,200 \\
\hline $04 \mathrm{C}$ & 5.0 & 12.82 & $>8.13$ & 5.41 & Reactive & 8,200 \\
\hline $06 \mathrm{~T}$ & 4.4 & 13.22 & 7.76 & 5.48 & Reactive & $<600$ \\
\hline 07B & 6.9 & 13.12 & $>8.13$ & $>5.59$ & Reactive & $<600$ \\
\hline $08 \mathrm{~T}$ & 6.8 & 13.32 & $>8.13$ & $>5.59$ & Reactive & $<600$ \\
\hline 09A & 3.7 & 13.05 & 7.95 & $>5.59$ & Reactive & $<600$ \\
\hline $10 \mathrm{G}$ & 5.6 & 13.18 & 7.98 & $>5.70$ & Reactive & $<600$ \\
\hline $11 \mathrm{R}$ & 4.1 & 12.99 & 6.63 & $>5.70$ & Reactive & $<600$ \\
\hline $13 \mathrm{G}$ & 2.7 & 13.26 & 8.06 & $>5.70$ & Reactive & $<600$ \\
\hline $14 \mathrm{O}$ & 6.0 & 13.26 & 6.82 & $>5.55$ & Reactive & $<600$ \\
\hline $15 \mathrm{P}$ & 0.5 & 1.97 & 0.33 & $>5.45$ & Reactive & 13,700 \\
\hline $17 \mathrm{~V}$ & 7.2 & 13.34 & $>8.36$ & 5.16 & Reactive & $<600$ \\
\hline $18 \mathrm{P}$ & 4.4 & 13.14 & $>8.36$ & 5.21 & Reactive & $<600$ \\
\hline 19J & 6.3 & 13.17 & $>8.36$ & $>5.33$ & Reactive & $<600$ \\
\hline $20 \mathrm{~V}$ & 7.1 & 13.05 & $>8.36$ & $>5.33$ & Reactive & 53,500 \\
\hline $21 \mathrm{~L}$ & 5.5 & 13.21 & $>8.36$ & $>5.33$ & Reactive & 15,300 \\
\hline $22 \mathrm{R}$ & 6.1 & 13.23 & $>8.36$ & $>5.33$ & Reactive & $<600$ \\
\hline $24 \mathrm{C}$ & 5.9 & 13.14 & $>8.36$ & $>5.55$ & Reactive & $<600$ \\
\hline $26 \mathrm{~A}$ & 0.4 & 1.20 & 2.45 & $>5.55$ & Reactive & $<600$ \\
\hline $27 R$ & 7.1 & 13.09 & $>8.36$ & $>5.55$ & Reactive & 2,000 \\
\hline
\end{tabular}

EIA results are expressed as a ratio between the mean of the optical density of each sample and the cut-off value. Ratio $>1.1$ was considered positive. 
TABLE II

Detection of antibodies against hepatitis $\mathrm{C}$ virus in a follow-up of a patient infected through blood transfusion

\begin{tabular}{lcccccccc}
\hline $\begin{array}{l}\text { Days after } \\
\text { transfusion }\end{array}$ & AST & ALT & $\begin{array}{c}\text { Detect } \\
\text { HCVTM }\end{array}$ & $\begin{array}{c}\text { EIA Wiener } \\
\text { (anti-HCV) }\end{array}$ & $\begin{array}{c}\text { Equipar } \\
\text { HCV Ab }\end{array}$ & $\begin{array}{c}\text { Murex } \\
\text { HCV }\end{array}$ & $\begin{array}{c}\text { Serodia } \\
\text { HCV PA }\end{array}$ & $\begin{array}{c}\text { Viral load } \\
\text { IU/ml }\end{array}$ \\
\hline 60 & 882 & 1392 & 0.69 & 0.22 & 0.12 & 5.28 & + & NT \\
81 & 118 & 215 & 0.65 & 1.52 & 0.26 & 5.33 & + & NT \\
100 & $\mathrm{NT}$ & $\mathrm{NT}$ & 0.54 & 1.97 & 0.33 & $>5.54$ & + & 13,700 \\
144 & 48 & 46 & 1.20 & 9.90 & 1.95 & $>5.54$ & + & $\mathrm{NT}$ \\
204 & 42 & 58 & 4.30 & 13.44 & 4.07 & $>5.55$ & + & NT $a$ \\
\hline
\end{tabular}

ALT: alanine amino-transferase; AST: aspartate amino-transferase; NT: not tested; $a$ : positive result by qualitative in house RTnested PCR; EIA results are expressed as a ratio between the mean of the optical density of each sample and the cut-off value. Ratio $>1.1$ was considered positive.

detected specific antibodies after 60 days post transfusion (1st sample taken). At that time, the subject had elevated levels of alanine amino-transferase (ALT) and aspartate amino-transferase (AST), as a consequence of viral infection (Table II). At day 60 after transfusion, the sample tested negative by Detect-HCV ${ }^{\mathrm{TM}}$, Equipar HCV Ab and EIA Wiener (anti-HCV) tests (Table II). The EIA Wiener (anti-HCV) began to detect the antibodies 81 days post transfusion with a low OD/CO value (Table II). Moreover, the antibodies were detected by Detect-HCV and Equipar $\mathrm{HCV}$ after 100 days postransfusion. At that time the patient had a viral load of $13700 \mathrm{UI} / \mathrm{ml}$ (Table II).

Thus, the sensitivity of these assays in the follow-up of a subject with HCV infection was of $100 \%$ for Murex HCV and Serodia-HCV PA, $83.3 \%$ for EIA Wiener (anti$\mathrm{HCV}$ ) and $62.5 \%$ for Detect-HCV ${ }^{\mathrm{TM}}$ and Equipar HCV Ab.

\section{DISCUSSION}

Anti-HCV assays are useful in diagnosing exposure to virus but provide no evidence in infected individuals during the antibody-negative phase. The long "serological window" refers to the period between HCV infection and detection of specific antibodies. With current assays, seroconversion occurs on an average of 70 to 80 days after the onset of infection (Schreiber et al. 1996, Muerhoff et al. 2002).

Over the last two decades, the risk of virus transmission through blood transfusions has been dramatically reduced. A study carried out by Donahue et al. (1992) demonstrated that before the introduction of the first assay for anti-HCV detection in 1990, the risk of transmission for each unit of blood transfused was $0.45 \%$, while the implementation of this technique lowered the risk to $0.03 \%$. The risk of transmission was further reduced following the introduction of second and third generation assays in 1992 and 1996, respectively (Kleiman et al. 1997, Stramer et al. 1998).

In spite of the introduction of third generation assays, the residual risk of transmission of $\mathrm{HCV}$ is estimated in 8:1,000,000 in the US, 1:100,000 in Germany and 1:370,000 in France (Koemer et al. 1998, Holland 2000, Pillonel et al. 2002).

In Argentina, the estimated risk of transmission of $\mathrm{HCV}$ by transfusion was 23.17 in 10,000 donations in 1995 . This risk decreased to 4.93 and 4.48 in 1996 and 1997, respectively (Schmuñis et al. 2000).
Currently, the screening of HCV in Argentina is based on anti-HCV detection using second or third generation assays.

In the present study, the sensitivity of different assays commercially available in Argentina for anti-HCV detection was evaluated. The objective of the study was to determine which of the assays has the best sensitivity to be used for detection of anti-HCV antibodies.

We assessed the sensitivity of five screening tests for the detection of anti-HCV antibodies in 22 serum samples of Argentinean subjects with HCV infection confirmed by PCR. Our results demonstrate a great variability in the sensitivity of the assays evaluated. The higher sensitivity values corresponded to Murex HCV and SerodiaHCV PA (100\%), the EIA test Wiener (anti-HCV) showed intermediate sensitivity $(83.3 \%)$ and lower values were observed with Detect-HCV ${ }^{\mathrm{TM}}$ and Equipar HCV Ab $(62.5 \%)$ (Table I).

In addition, greater discrepancies in screening tests were observed in serum samples of early stage of infection. Detect-HCV ${ }^{\mathrm{TM}}$ and Equipar HCV failed to detect antibodies in a subject with post-transfusional HCV infection at 60, 81, and 100 days after transfusion (Table II).

Since screening assays for HCV antibodies were first introduced around 10 years ago, major efforts have been made to increase both sensitivity and specificity. It has been postulated that this could be done including a greater number of HCV-encoded antigens in subsequent assays, thus favoring specific over non-specific antibody detection. Considering this inconvenience, the manufacturers have attempted to improve specificity by eliminating falsepositive reactions that may result in an increased risk for false-negative interpretations.

The tests analyzed in this study have different antigenic configuration: Equipar HCV Ab has synthetic peptides, Murex HCV and Serodia-HCV PA have recombinant proteins and Detect-HCV ${ }^{\mathrm{TM}}$ and EIA Wiener anti-HCV have a combination of both antigens.

The tests that demonstrated the best sensitivity in this study used an antigenic configuration composed by recombinant proteins. It has been reported that differences in sensitivity do not depend on the nature of the antigens used by the kit. Leon et al. (1994), did not find significant differences between the sensitivity of the assays that used recombinant or synthetic peptides as antigens. 
In order to avoid $\mathrm{HCV}$ transmission from donors, who may be at the window period, blood banks of the United States and the European Union require HCV RNA testing for blood screening. Testing is based on detection of RNA by nucleic acid amplification technology (NAT) (PaulEhrlich-Institut 1998, Stramer et al. 2000).

Even though the introduction of NAT has clearly reduced the infectivity of blood products and narrowed the window period by 59 days, it is an expensive and time consuming assay (Schreiber et al. 1996, Busch et al. 1997, Jackson et al. 2003). Due to the high cost of this technique, blood banks of Argentina are still not able to use NAT as a screening tool.

A new test has recently been developed to detect the $\mathrm{HCV}$ core protein $[\mathrm{HCV}$ antigen $(\mathrm{Ag})]$, which is coded for one of the most conserved region of the virus genome. This test reduces the window period for detection of potentially infected blood donors and represents an available alternative to HCV RNA testing at a lower cost. Additionally, HCV-Ag kits have demonstrated similar sensitivity compared with NAT (Courouce et al. 2000, Icardi et al. 2001, Muerhoff et al. 2002). These tests are still not available in Argentina.

On the other hand, our results show that the serum samples that were anti-HCV negative at 60 and 81 days using Detect-HCV ${ }^{\mathrm{TM}}$ and Equipar HCV Ab assays had increased levels of serum transaminase (ALT) (Table II). In this case, the detection of an elevated ALT could have been helpful as a subrogate marker of viral infection. However, several studies have demonstrated that the discard of blood units due to high levels of ALT is controversial due to the lack of specificity of the test. (Lozano et al. 1998, Delle Monache et al. 1999).

In Argentina, the use of the most sensitive available techniques for HCV screening is one of the most important factors that affect blood quality, since repetitive altruist donations are exceptional and the majority of them are replacement donations. It has been demonstrated that first time donors have higher prevalences of infectious diseases than repetitive donors (Glynn et al. 2000).

Finally, the results of this study indicate that of the commercially available kits in Argentina, Murex HCV and Serodia HCV PA show the best sensitivity for HCV screening. However, more studies should be carried out to assess the specificity of these assays. Moreover, it is necessary to carry out continuous studies of quality control of antibody screening techniques in order to improve the HCV screening until the NAT assays or viral antigen detection assays become available in the country.

\section{ACKNOWLEDGEMENTS}

To Wiener Laboratories, Rosario, Argentina, for providing the equipment used in this study. To the donor for having provided all the samples. To Miss Valeria Mosqueda and Miss Lorena Riquelme for revising the language style of the manuscript. To Jaqueline Mendes de Oliveira (Instituto Oswaldo Cruz, Rio de Janeiro, Brasil) for comments and critical reading of the manuscript.

\section{REFERENCES}

Aach R, Stevens C, Hollinger H, Mosley J, Peterson D, Tylor P, Johnson R, Barbosa L, Nemo G 1991. Hepatitis C virus infection in post-transfusion hepatitis. An analysis with first- and second- generation assays. New Engl J Med 325: 1325-1329.

Busch MP, Stramer SL, Kleinman SH. 1997 Evolving applications of nucleic acid amplification assays for prevention of virus transmission by blood components and derivatives. In G Garraty, Applications of Molecular Biology to Blood Transfusion Medicine, American Association of Blood Banks, Bethesda, p. 123-177.

Colin C, Lanoir D, Touzet S, Meyaud-Kraemer L, Bailly F, Trepo C 2001. Sensitivity and specificity of third-generation hepatitis $\mathrm{C}$ virus antibody detection assays: analysis of the literature. $J$ Viral Hep 8: 87-95.

Courouce AM, Le Marrec N, Bouchardeau F, Razer A, Maniez M, Laperche S, Simon N 2000. Efficacy of HCV core antigen detection during the preseroconversion period. Transfusion 40: 1198-1202.

Delle Monache M, Micelli M, Santolamazza M, Mannella E, Mercurio G, Di Lorenzo A, Bacosi M, Gerardi R, Berardo C, Bruno G, Russo F, Miglioresi L, Ricci GL 1999. Elevated alanine aminotranferase in blood donors: role of different factors and multiple viral infections. J Int Med Res 27: 134-142.

Donahue J, Muñoz A, Ness P, Brown Jr DE, Yawn DH, McAllister Jr HA, Reitz BA, Nelson KE 1992. The declining risk of posttransfusion hepatitis $\mathrm{C}$ virus infection. $N$ Engl J Med 327: 369-373.

Glynn SA, Kleinman SH, Schreiber GB, Busch MP, Wright DJ, Smith JW, Nass CC, Williams AE 2000. Trends in incidence and prevalence of major transfusion-transmissible viral infections in US blood donors, 1991 to 1996. Retrovirus Epidemiology Donor Study (REDS). JAMA 284: 229-235.

Holland P 2000. Old and new tests. Where will it end? Vox Sang 78: $67-70$.

Icardi G, Ansaldi F, Bruzzone BM, Durando P, Lee S, de Luigi C, Crovari P 2001. Novel approach to reduce the hepatitis $\mathrm{C}$ virus (HCV) window period: clinical evaluation of a new enzyme-linked immunosorbent assay for HCV core antigen. J Clin Microbiol 39: 3110-3114.

Jackson BR, Busch MP, Stramer SL, AuBuchon JP 2003. The cost-effectiveness of NAT for HIV, HCV, and HBV in wholeblood donations. Transfusion 43: 721-729.

Janot C, Courucé AM, Bourdart D, Cotte C, Elghouzzi MH, Jullien AM, Lemaire JM, Maisonneuve P, ManiezMontreuil M, Mattlinger B 1992. Analytical study of Abbot and Ortho tests for screening and confirmation of antiHCV antibodies. Le Group de Travail Hépatites Virales de la Societé Francaise de Transfusion Sanguine. Rev Fr Transf Hemobiol 35: 171-182.

Kleinman S, Alter H, Busch M, Holland P, Tegtmeier G, Nelles M, Lee S, Page E, Wilber J, Polito A 1992. Increased detection of hepatitis $\mathrm{C}$ virus (HCV) infected blood donors by multiple antigens HCV enzyme immunoassay. Transfusion 32: $806-813$

Kleiman S, Busch M, Korelitz J, Schereiber G 1997. The incidence/window period model and its use to assess the risk of transfusion-transmitted HIV and HCV viral infection. Transfus Med Rev 11: 155-172.

Koemer K, Cardoso M, Dengler T, Kerowgan M, Kubanek B 
1998. Estimated risk of transmission of hepatitis C virus by blood transfusion. Vox Sang 78: 213-216.

Leon P, Lopez J, Elola C, Domingo CJ, Echevarria JM 1994. Are synthetics peptides sensitive enough for screening anti hepatitis C virus at blood banks? Vox Sang 67: 83-84.

Lozano M, Cid J, BediniJL, Mazzara R, Jiménez N, Mas E, Ballesta A, Ordinas A 1998. Study of serum alanine-aminotransferase levels in blood donors in Spain. Haematologica 83: 237-239.

Lunel F, Rosenheim M, Duneton P 1996. Proposition pour une stratégie d'évaluation et d'utilisation des tests de déspistage de l'hépatite C. Transf Clin Biol 5: 279-288.

Majid AM, Gretch DR 2002. Current and future hepatitis C virus diagnostic testing: problems and advancements. $\mathrm{Mi}$ crobes and Infection 4: 1227-1236.

Mendes de Oliveira J, Rispeter K, Viazov S, Saback F, Roggendorf M, Yoshida C 2001. Differences in HCV antibody patterns in haemodialysis patients infected with the same virus isolate. J Med Virol 63: 265-270.

Morishima CG 1999. Clinical use of hepatitis C virus tests for diagnosis and monitoring during therapy. Clin Liver Dis 3: 717-740.

Muerhoff AS, Jiang L, Shah DO, Gutierrez RA, Patel J, Garolis C, Kyrk CR, Leckie G, Frank A, Stewart JL, Dawson GJ 2002. Detection of HCV core antigen in human serum and plasma with an automated chemiluminescent immunoassay. Transfusion 42: 349-356.

Paul-Ehrlich-Institut, Bundesamt für sera und Impfstoffe 1998. Results of the phased plan to reduce the infection risk in hepatitis B, C and HIV in recipients of packed red cell transfusions (German). Bundesanzeinger 53: 3835-3836.

Pillonel J, Laperche S, Saura C, Desenclos JC, Courouce AM 2002. Transfusion-Transmissible Agents Working Group of the French Society of Blood Transfusion. Trends in residual risk of transfusion-transmitted viral infections in France between 1992 and 2000. Transfusion 42: 980-988.

Schmuñis G, Zicker F, Segura E, del Pozo A 2000. Transfusiontransmitted infectious diseases in Argentina, 1995 through 1997. Transfusion 40: 1048-1053.

Schreiber G, Busch M, Kleinman S, Korelitz J 1996. The risk of transfusion-transmitted viral infections. N Engl J Med 334: 1685-1690.

Stramer SL, Caglioti S, Smong DM 2000. NAT of United States and Canadian blood supply. Transfusion 40: 1165-1168.

Stramer SL, Porter RA, Brodsky JP 1998. Sensitivity of HIV and HCV RNA detection by pooled genome amplification testing (GAT). Transfusion 38: 70.

Van der Poel CL, Cuypers HT, Reesink HW 1994. Hepatitis C virus, six years on. Lancet 344: 1475-1479.

Van der Poel C, Cuypers H, Reesink H, Choo Q, Kuo G, Hon J, Quon S, Polito A, Verstrater J, Van der Wouw J 1991. Risk factors in hepatitis $\mathrm{C}$ virus-infected blood donors. Transfusion 31: 777-779.

Weber B, Rabenau H, Berger A, Scheuermann EH, Staszewski S, Kreuz W, Scharrer I, Schoeppe W, Doerr HW 1995. Seroprevalence of HCV, HAV, HBV, HDV, HCMV and HIV in high risk groups, Frankfurt a. M., Germany. Zentralbl Bateriol 282: 102-112. 
